\title{
Effect of Soil Moisture Content and Rate of Potassium Fertilizer \\ on Soil Potassium Content and Growth of Cowpea (Vigna unguiculata 1.) Grown in Sandy Regosol in Sri Lanka
}

\author{
Vassanthini, R. ${ }^{\mathrm{a}^{*}}$ and P.Premanandarajah ${ }^{\mathrm{b}}$ \\ a vassanthini93ratnarajah@gmail.com \\ ${ }^{a, b}$ Department of Agricultural Chemistry, Faculty of Agriculture, Eastern University, Sri Lanka
}

\begin{abstract}
A research study was conducted to identify the effect of potassium rate and drought stress on the post-harvest soil potassium content and growth parameters of cowpea (Vigna unguiculata L.). The experiment was arranged in a Completely Randomized Design (CRD) in a factorial manner with 8 treatments (4 different rates of fertilizer potassium as muriate of potash (MOP (i) 100\% of recommended level (75 kgha-1), (ii) 125\% of recommended level (93.75.kgha-1), (iii) $150 \%$ of recommended level (112.5 kgha-1), and (iv) 175\% of recommended level (131.25.kgha-1) at 2 different soil moisture conditions as $25 \%$ depletion and $75 \%$ depletion of available soil moisture as optimal and sub-optimal moisture condition respectively and was replicated 3 times. The post-harvest soil potassium content, chlorophyll content of leaves and cowpea growth parameters such as, dry weight of root and dry weight of shoot were recorded at vegetative and harvesting stages. The results reveal that there was a significant influence $(\mathrm{p}<0.05)$ of potassium rate and soil moisture on the growth parameters, leaf chlorophyll content and available soil potassium content after harvest. In overall terms potassium promoted growth of cowpea when subject to sub-optimal soil moisture. Further, it was found that the increased application of potassium fertilizer up to $175 \%$ of recommended level can be considered as a significant factor in overcoming soil moisture stress in cowpea.
\end{abstract}

Published by IJRP.ORG. Selection and/or peer-review under responsibility of International Journal of Research Publications (IJRP.ORG)

Keywords: Cowpea; Growth; Moisture stress; Potassium; Sandy regosol

\section{Introduction}

Sri Lanka is an agriculture based developing country, which is highly impacted by the growing population. Due to this, food security has become a major issue in Sri Lanka. Therefore, enhancing the crop productivity to ensure food security is more important to provide better nutrition to the people and to increase their standard of living. 
Drought has been a severe abiotic stress in Sri Lanka which has resulted in significant negative impact on crop production and agriculture. According to the Disaster Management Centre of Sri Lanka it was reported that, there were over 312,000 people in 14 districts in 8 provinces affected by drought as of May 2020.

Cowpea (Vigna unguiculata L.) is rich in seed protein (33\%), (Ddamulira and Santos, 2015) and are cultivated and consumed in different forms in several parts of the tropics including Sri Lanka. Cowpea is often subjected to drought stress in both seedling and terminal growth stages which cause a considerable amount of loss in biomass production (Amos and Christopher, 2017). Among the plant nutrients, potassium (K) is an essential plant nutrient and is required in large amounts for proper growth and reproduction of plants (Betül and Ali, 2017). Both uptake of water through plant roots and its loss through the stomata are affected by potassium. Potassium plays a major role in the regulation of stomatal opening in plants to improve drought resistance (Mirza Hasanuzzaman et al., 2018).

A better understanding of the effects of water stress on cowpea growth and physiology will give farmers useful information on how to manage cowpea production in conditions of drought, and also a few studies have demonstrated that the use of potassium fertilizer can reduce the adverse effects of water stress in cowpeas in controlled environmental conditions (Fooladivanda et al., 2014). Therefore, to investigate this possibility; an experiment was carried out under exposed environmental conditions in the sandy regosols of Batticaloa district to determine the impact of potassium fertilizer on the soil potassium content and growth of cowpea under two different soil moisture conditions and to select the best combination of potassium level and soil moisture condition for the optimum growth of cowpea.

\section{Methodology}

\subsection{Collection of soil sample and seeds}

Sandy regosol soil was collected from the surface layer $(0-15 \mathrm{~cm})$ of the Agronomy farm, Eastern University, Sri Lanka and cowpea seeds of Wijaya variety were used for this experiment.

\subsection{Experimental design and preparation of treatments}

\subsubsection{Experimental design}

A pot experiment was conducted at the Eastern University, Sri Lanka for a period of 3 months from July to September, 2018. The experiment was arranged in a factorial complete randomized design with eight treatments (4 different rates of fertilizer potassium (MOP): (i) 100\% of recommended level(75 kgha-1), (ii) $125 \%$ of recommended level, (iii) $150 \%$ of recommended level and (iv) $175 \%$ of recommended level, with 2 different soil moisture conditions as optimal and sub-optimal) with three replicates with rain proof roof. Nitrogen and phosphorus fertilizers were incorporated with the soil as per the Department of Agriculture (DOA) recommendation and potassium was incorporated according to the treatments. According to the Department of Agriculture recommendation, the optimum potassium level for cowpea is $75 \mathrm{~kg} / \mathrm{ha}$.

\subsubsection{Soil moisture control}

Soil's field capacity (52\%) was measured in volume basis (Wang et al., 2013). Depletion of available soil moisture at 25 and $75 \%$ were determined in volume basis and defined as optimal moisture condition and sub- 
optimal moisture condition, respectively. Soil moisture was monitored at every two days interval by weighing the bags (Felício Lopo de Sá et al., 2014).

\subsubsection{Treatment structure}

F1K0 -Sub-optimal moisture condition+potassium at $100 \%$ of recommendation (control)

F1K1 -Sub-optimal moisture condition+potassium at $125 \%$ of recommendation

F1K2 -Sub-optimal moisture condition+potassium at $150 \%$ of recommendation

F1K3 -Sub-optimal moisture condition+potassium at $175 \%$ of recommendation

F2K0 -Optimal moisture condition+potassium at $100 \%$ of recommendation (control)

F2K1 -Optimal moisture condition+potassium at $125 \%$ of recommendation

F2K2 -Optimal moisture condition+potassium at $150 \%$ of recommendation

F2K3 -Optimal moisture condition+potassium at $175 \%$ of recommendation

According to the recommended rate, treatments were applied to the bag three days before sowing.

\subsection{Measurements}

Growth parameters (Dry weight of root and leaf (g)-roots of uprooted plants were oven dried at 70 0c for 72 hours and dry weight was measured using an electronic balance, Chlorophyll content of leaves-measured by SPAD meter) were measured to evaluate the growth performances of cowpea in each treatment at vegetative (30 days after sowing (DAS)) and harvesting stages (60 DAS). Soil potassium content (mg/kg) was also measured (by flame photo meter).

\subsection{Statistical analysis}

All the data were analyzed by Analysis of Variance (ANOVA) $(\alpha=0.05)$ using SAS 9.1.3 statistical software and the differences between means was compared using Duncan's Multiple Range Test (DMRT).

\section{Results and discussion}

\subsection{Available potassium in soil at harvest}

The results pertaining to the post-harvest soil potassium content indicated that there was a significant influence of fertilizer potassium and soil moisture on the available soil potassium at harvest (Table 1).

The results obtained showed that the available potassium level increased with increasing level of fertilizer potassium in both moisture conditions. But the available soil potassium rates were comparatively higher in optimal moisture condition than the sub-optimal. This deviation was may be due to the differences in root growth. 
Table 1: Effect of soil moisture content and potassium fertilizer on the available potassium content of soil $(\mathrm{mg} / \mathrm{Kg})$ at harvest.

\begin{tabular}{lll}
\hline \multirow{2}{*}{$\begin{array}{l}\text { Rate of } \\
\text { MOP }\end{array}$} & $\begin{array}{l}\text { Soil K }(\mathrm{mg} / \mathrm{Kg}) \\
\text { Sub-optimal Soil moisture } \\
\text { content }\end{array}$ & $\begin{array}{l}\text { Optimal Soil moisture } \\
\text { content }\end{array}$ \\
\hline $\begin{array}{ll}\text { Control } \\
(100 \%)\end{array}$ & $40.27 \pm 0.204^{\mathrm{d}}$ & $10624.1 \pm 34.36^{\mathrm{c}}$ \\
$125 \%$ & $4323.0 \pm 25.62^{\mathrm{c}}$ & $18838.0 \pm 45.37^{\mathrm{b}}$ \\
$150 \%$ & $9447.0 \pm 42.12^{\mathrm{b}}$ & $20698.2 \pm 12.1^{\mathrm{bc}}$ \\
$175 \%$ & $11908.0 \pm 35.26^{\mathrm{a}}$ & $33074.1 \pm 26.0^{\mathrm{a}}$ \\
\hline & Moisture content & $P<0.05$ \\
& MOP & $P<0.05$ \\
& Interaction & $P<0.05$ \\
\hline
\end{tabular}

The values are means of replicates \pm standard error.

Means with the same letter(s) are not significantly different from each other according to the Duncan multiple range test at $5 \%$ significant level.

Root growth was higher under sub-optimal condition to enable to access more moisture in soil. For the growth of root potassium is needed, and the uptake of potassium under water stress may be high. Thereby this may cause the reduction of available soil potassium in the sub-optimal condition. This was supported by (Carmeis Filho et al., 2017) who found that potassium added to the soil increased the root growth.

\subsection{Leaf dry weight}

The results pertaining to the leaf dry weight of cowpea plant indicated that there was a significant influence $(\mathrm{P}<0.05)$ of soil moisture and potassium fertilizer on the leaf dry weight at both vegetative and harvesting stages.

At vegetative stage, among the treatments greater values were received under sub-optimal moisture condition compared to optimal. This may be due to the leaf thickening by higher accumulation of photosynthates to overcome the moisture stress. This was supported by with similar data on peanuts (Craufurd et al., 1999). However, at the harvesting stage, leaf dry weight was low under the sub-optimal moisture condition compared to optimal. Similar findings were observed by (Samson and Helmut, 2007) in cowpea. This may be due to the reduction of photochemical yield during the prolonged dry condition. 

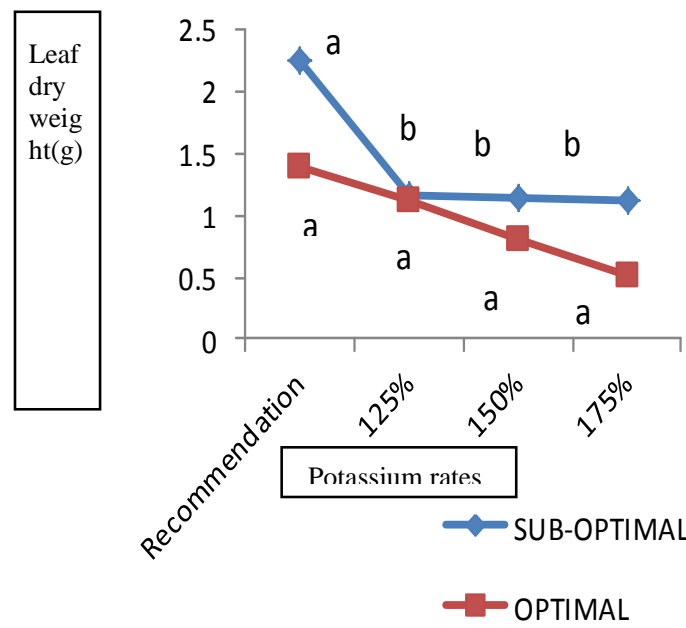

Fig.1: Effect of different soil moisture conditions and potassium rates on the leaf dry weight of cowpea at vegetative stage.

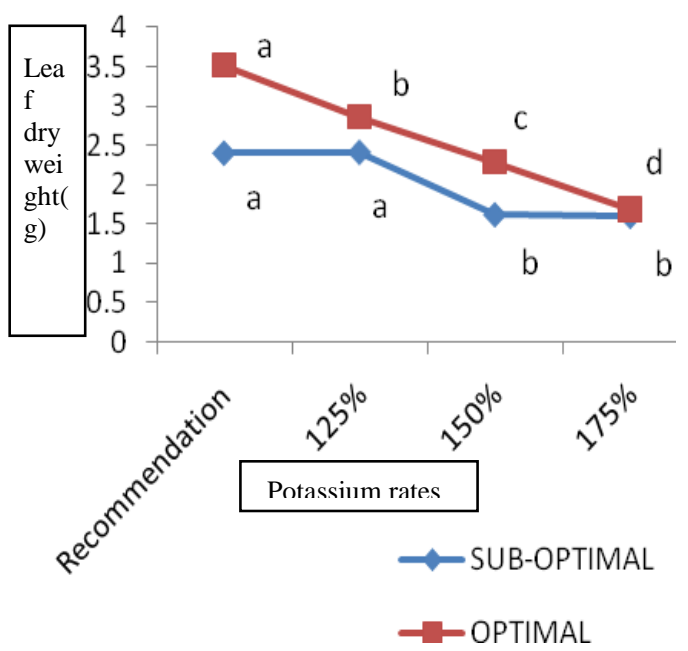

Fig.2: Effect of different soil moisture conditions and potassium rates on the leaf dry weight of cowpea at harvesting stage.

Application of potassium reduced leaf dry weight, and the impact was greater in $175 \%$ potassium level under both moisture conditions and at both growth stages. The reduction of leaf dry weight was may be due to the movement of photosynthates from the leaves to conducting tissues by the activity of potassium. This provides evidence of the possible role of potassium in the movement of photosynthates from leaves. This was supported by (Sangakkara et al., 2001). Results further reveal that there was no significant influence $(\mathrm{P}>0.05)$ by the interaction between moisture content and potassium rates at the vegetative stage.

At harvest interaction between moisture condition and potassium rates shows significant influence $(\mathrm{P}<0.05)$. Recommended level of potassium showed highest leaf dry weight difference among sub-optimal and optimal moisture conditions and was highest under optimal moisture condition (3.520g). This may be due to low level of potassium application. It means decreasing level of potassium application significantly increases leaf dry weight of cowpea at harvest. Under sub-optimal condition significantly highest value was observed at recommended level and was on par with $125 \%$ level. The value was significantly low at $175 \%$ potassium level. This indicates that increasing level of fertilizer potassium significantly reduces the leaf dry weight under sub-optimal moisture conditions. Sangakkara et al. (2001) stated that increasing potassium level will reduce the leaf dry weight especially under soil moisture stress. The reduction in the leaf dry weight with increasing level of potassium may be due to the movement of photosynthates from leaf to reproductive parts. Pujos and Morard, (1997) stated that in fruit vegetables potassium is remobilized from the leaves and the stem and transferred largely to the fruits. 


\subsection{Root dry weight}

The results pertaining to the root dry weight of cowpea plant indicated that there was a significant influence $(\mathrm{P}<0.05)$ of soil moisture content and potassium on the dry weight of root at both vegetative and harvesting stages (Table 2).

At both stages, among the treatments highest value was received in sub-optimal moisture condition. It may be due to increased root length under water stress conditions in order to search water in the deeper layers of dry soil. It shows that the sustained growth of roots is the factor of resistance to water stress under water deficit conditions. This is supported by (Monneveux, 1997). Sangakkara et al. (2001) stated that dry matter partitioning is high to roots under moisture stress.

Table 2: Effect of soil moisture content and potassium rates on the root dry weight of cowpea

\begin{tabular}{|c|c|c|c|}
\hline & & Root dry weight (g) & \\
\hline $\begin{array}{l}\text { Growth } \\
\text { stage }\end{array}$ & Rate of MOP & $\begin{array}{l}\text { Sub-optimal soil } \\
\text { moisture content }\end{array}$ & $\begin{array}{l}\text { Optimal soil } \\
\text { moisture content }\end{array}$ \\
\hline
\end{tabular}

\begin{tabular}{llll}
\hline Vegetative & Control (100\%) & $0.316 \pm 0.017^{\mathrm{b}}$ & $0.160 \pm 0.017^{\mathrm{b}}$ \\
& $125 \%$ & $0.296 \pm 0.132^{\mathrm{b}}$ & $0.170 \pm 0.011^{\mathrm{b}}$ \\
$150 \%$ & $0.360 \pm 0.015^{\mathrm{b}}$ & $0.193 \pm 0.045^{\mathrm{b}}$ \\
$175 \%$ & $0.466 \pm 0.040^{\mathrm{a}}$ & $0.280 \pm 0.017^{\mathrm{a}}$ \\
\hline Moisture content & $P<0.05$ & \\
& MOP & $P<0.05$ & \\
\hline Harvesting & Control (100\%) & $0.680 \pm 0.015^{\mathrm{c}}$ & $0.384 \pm 0.020^{\mathrm{b}}$ \\
\hline & $125 \%$ & $0.720 \pm 0.012^{\mathrm{c}}$ & $0.560 \pm 0.035^{\mathrm{a}}$ \\
& $150 \%$ & $1.163 \pm 0.027^{\mathrm{b}}$ & $0.596 \pm 0.002^{\mathrm{a}}$ \\
& $175 \%$ & $1.508 \pm 0.176^{\mathrm{a}}$ & $0.623 \pm 0.018^{\mathrm{a}}$ \\
\hline & Moisture content & $P<0.05$ & \\
& MOP & $P<0.05$ & \\
& Interaction & $P<0.05$ & \\
\hline
\end{tabular}

The values are means of replicates \pm standard error

Means with the same letter(s) are not significantly different from each other according to the Duncan multiple range test at 5\% significant level.

At vegetative stage increasing level of fertilizer potassium increased the root dry weight of cowpea. Especially $175 \%$ potassium level significantly increased the root dry weight. There is no significant differences were observed between recommended, $125 \%$ and $150 \%$ potassium levels. This may be due to the translocation of photo-assimilates to root. Römheld and Kirkby, (2010) stated that potassium is essential for the translocation of photo-assimilates in root growth and increased supply of potassium increase the root surface and root water uptake. It shows that increased application of fertilizer potassium helps to overcome the moisture stress. At harvest significantly highest root dry weight of cowpea was observed at the rate of $175 \%$ and $150 \%$ level ranked the second under sub-optimal moisture. Increasing level of fertilizer potassium 
increased the root dry weight under sub-optimal condition at harvest. Islam et al. (2004) confirmed that the root volume and root dry weight measured at harvest remarkably increased with the decrease in the moisture level. Under optimal condition $125 \%, 150 \%$, and $175 \%$ increased the root dry weight and there is no significant differences observed between them.

\subsection{Chlorophyll content of leaves at vegetative stage}

The results pertaining to the chlorophyll content of the leaves of cowpea plant indicated that there was a significant influence $(\mathrm{P}<0.05)$ of soil moisture content and fertilizer potassium on the chlorophyll content of cowpea plants at vegetative stage (Table 3 ).

Table 3: Effect of soil moisture content and potassium rates on the chlorophyll content of leaves of cowpea at vegetative stage.

\begin{tabular}{lll}
\hline \multirow{2}{*}{ Rate of MOP } & \multicolumn{2}{l}{ Leaf Chlorophill content $(\mathrm{mg} / \mathrm{Kg})$} \\
\cline { 2 - 3 } & $\begin{array}{l}\text { Sub-optimal soil } \\
\text { moisture cotent }\end{array}$ & $\begin{array}{l}\text { Optimal soil moisture } \\
\text { content }\end{array}$ \\
\hline Control (100\%) & $49.616 \pm 0.122^{\mathrm{a}}$ & $51.400 \pm 0.579^{\mathrm{a}}$ \\
$125 \%$ & $50.733 \pm 0.050^{\mathrm{a}}$ & $52.500 \pm 0.388^{\mathrm{a}}$ \\
$150 \%$ & $51.000 \pm 0.305^{\mathrm{b}}$ & $52.700 \pm 0.132^{\mathrm{a}}$ \\
$175 \%$ & $52.666 \pm 0.050^{\mathrm{b}}$ & $52.700 \pm 0.491^{\mathrm{a}}$ \\
\hline & Moisture content & $P<0.05$ \\
& MOP & $P<0.05$ \\
& Interaction & $P>0.05$ \\
\hline
\end{tabular}

The values are means of replicates \pm standard error

Means with the same letter(s) are not significantly different from each other according to the Duncan multiple range test at $5 \%$ significant level.

Plants under optimal moisture conditions displayed greater chlorophyll contents than under sub-optimal moisture conditions (Table 3). Decreased chlorophyll contents have been reported for many crop species under soil moisture stress (Massacci et al., 2008 and Guha et al., 2010). Chathurika et al. 2019 reported that the soil moisture stress-induced reduction in chlorophylls is considered as an indicator of oxidative stress which is attributed to chlorophyll degradation, and insufficient synthesis of chlorophylls.

Under sub-optimal moisture content chlorophyll content was significantly increased at $175 \%$ compared with the lower rates (125\%) and the control. Nyoki and Ndakidemi, (2016) reported that, increasing the level of fertilizers had positive effects on chlorophyll content of soybean leaves. This observation agrees with Watanabe and Yoshida, (1970), who stated that deficiency phosphorus and potassium causes changes in the structure of chloroplasts and may affect the biochemical activity of chloroplast resulting to low leaf chlorophyll content. 


\section{Conclusion and suggestions}

In the present study, plants grown at potassium rate at $175 \%$ of recommendation showed significantly better performances in soil potassium content and plant growth parameters. It might be due to the activity of potassium which regulates the stomatal opening and makes the plants adaptive to drought stress. From the findings it could be concluded that, application of potassium rate at $175 \%$ of recommendation could be recommended for cowpea (Vigna unguiculata L.) cultivation as a better option to improve growth under moisture stress conditions. As this study was performed as a pot experiment, the same should be undertaken under field conditions to ensure the results.

\section{References}

Amos Afolarin Olajide., Christopher Olumuyiwa Ilori., 2017. Effects of drought on morphological traits in some cowpea genotypes by evaluating their combining abilities. Advances in Agriculture. 2017, p.1-10.

Betül Çalişkan., Ali Cengiz Çalişkan., 2017. Potassium Nutrition in Plants and Its Interactions with Other Nutrients in Hydroponic Culture, Potassium - Improvement of Quality in Fruits and Vegetables Through Hydroponic Nutrient Management, Md Asaduzzaman and Toshiki Asao, IntechOpen,

Carmeis Filho., Antonio Carlos De Almeida Crusciol., Carlos Alexandre Costa., Nascente Adriano Stephan., Mauad Munir., Garcia Rodrigo Arroyo., 2017.Influence of potassium levels on root growth and nutrient uptake of upland rice cultivars.Revista Caatinga.30(1), p.32-44.

Chathurika Wijewardana., Firas, A., Alsajri, J., Trenton Irby, L., Jason Krutz, Bobby Golden, W., Brien Henry, Wei Gao., K. Raja Reddy (2019) Physiological assessment of water deficit in soybean using midday leaf water potential and spectral features, Journal of Plant Interactions, 14:1, p.533-543.

Craufurd, T. R., Wheeler, R.H., Ellis, R.J., Summerfield, J.H., Williams, W.A.J.M., 1999. Effect of temperature and water deficit on water use efficiency, carbon isotope discrimination and specific leaf area in peanut. Crop Science. 39, p.136-142.

Ddamulira, G., Santos, C., 2015. Seed yield and protein content of Brazilian cowpea genotypes under diverse Mgandan environments. Am. J. Plant Sci. 6, p.2074.

Felício Lopo de Sá, A., Valiengo Valeri, S., Pessoa da Cruz, M., Barbosa, J., Machado Rezende, G. and Pozzetti Teixeira, M., 2014. Effects of potassium application and soil moisture on the growth of Corymbia citriodora plants. CERNE. 20(4), p.645-651.

Fooladivanda, Z., Hassanzadehdelouei, M., Zarifinia, N., 2014. Effects of water stress and potassium on quantity traits of two varieties of mung bean (Vigna radiata L.). Cercetari Agronomice in Moldova. 47, p.157.

Guha, A., Sengupta, D., Rasineni, G.K., Reddy, A.R., 2010. An integrated diagnostic approach to understand drought tolerance in mulberry (Morus indica L.). Flora-Morphol Dist Func Ecol Plants. 205, p.144-151.

Islam, M.S., Haque, M.M., Khan, M.M., Hidaka, T., Karim, M.M., 2004. Effect of fertilizer potassium on growth, yield and water relations of bushbean (Phaseolus vulgaris L.) under water stress conditions. Japan Journal of Tropical Agriculture. 48(1, p.1-9.

Massacci, A., Nabiev, S.M., Pietrosanti, L., Nematov, S.K., Chernikova, T.N., Thor, K., Leipner, J., 2008. Response of the photosynthetic apparatus of cotton (Gossypium hirsutum) to the onset of drought stress under field conditions studied by gasexchange analysis and chlorophyll fluorescence imaging. Plant Physiol Biochem. 46, p.189-195.

Mirza Hasanuzzaman., Borhannuddin Bhuyan, M.M., Kamrun Nahar., Shahadat Hossain, M., Jubayer Al Mahmud., Shahadat Hossen, M., Abdul Awal Chowdhury Masud., Moumita., Masayuki, Fujita., 2018. Potassium: A vital regulator of plant responses and tolerance to abiotic stresses. Agronomy. 8, p.31.

Monneveux, P., 1997. Genetics in the face of tolerance problems of crops grown during drought: hopes and difficulties. Science Global Change/Drought. 8(1), p.29-37.

Nyoki, Daniel., Ndakidemi, Patrick., 2016. Effects of Rhizobia Inoculation, Phosphorus and Potassium on Chlorophyll Concentration of Soybean Grown under Maize Intercropping System. International Journal of Plant \& Soil Science. 13, p.1-10.

Pujos, A., Morard, P., 1997. Effects of potassium deficiency on tomato growth and mineral nutrition at the early production stage. Plant and Soil. 189, p.189-196.

Römheld, V., Kirkby, E., 2010. Research on potassium in agriculture: needs and prospects. Plant and Soil. 335, p.155-180.

Samson, H., Helmut, H., 2007. Drought effect on yield, leaf parameters and evapotranspiration efficiency of cowpea. Conference of International Agricultural Research for Development, University of Kassel- Witzenhause and University of Gotteingen, October 2007.

Sangakkara, U., Frehner, M., Nosberger, J., 2001. Influence of soil moisture and fertilizer potassium on the vegetative growth of mungbean (Vigna radiata L. Wilczek) and cowpea (Vigna unguiculata L. Walp). Journal of Agronomy and Crop Science. 186(2), p.73-81.

Wang, M., Zheng, Q., Shen, Q. and Guo, S., 2013. The critical role of potassium in plant stress response. International Journal of Molecular Sciences. 14, p.7370-7390. 
Watanabe, H., Yoshida, S., 1970. Effects of nitrogen, phosphorus, and potassium on photophosphorylation in rice in relation to the photosynthetic rate of single leaves. Soil Sci Plant Nutr.16(4), p.163-166. 